Article

\title{
Assessment of Tangible Direct Flood Damage Using a Spatial Analysis Approach under the Effects of Climate Change: Case Study in an Urban Watershed in Hanoi, Vietnam
}

\author{
Mohamed Kefi ${ }^{1,2, *}$, Binaya Kumar Mishra ${ }^{1,2}$, Pankaj Kumar ${ }^{1}$ (D), Yoshifumi Masago $^{1}$ \\ and Kensuke Fukushi ${ }^{2}$ \\ 1 United Nations University Institute for the Advanced Study of Sustainability (UNU-IAS), 5-53-70 Jingumae, \\ Shibuya-ku, Tokyo 150-8925, Japan; mishra@unu.edu (B.K.M.); kumar@unu.edu (P.K.); \\ masago@unu.edu (Y.M.) \\ 2 Integrated Research System for Sustainability (IR3S), University of Tokyo, 7-3-1 Hongo, Bunkyo-ku, \\ Tokyo 113-8654, Japan; fukushi@ir3s.u-tokyo.ac.jp \\ * Correspondence: kefi@unu.edu
}

Received: 23 November 2017; Accepted: 10 January 2018; Published: 16 January 2018

\begin{abstract}
Due to climate change, the frequency and intensity of Hydro-Meteorological disasters, such as floods, are increasing. Therefore, the main purpose of this work is to assess tangible future flood damage in the urban watershed of the To Lich River in Hanoi, Vietnam. An approach based on spatial analysis, which requires the integration of several types of data related to flood characteristics that include depth, in particular, land-use classes, property values, and damage rates, is applied for the analysis. To simulate the future scenarios of flooding, the effects of climate change and land-use changes are estimated for 2030. Additionally, two scenarios based on the implementation of flood control measures are analyzed to demonstrate the effect of adaptation strategies. The findings show that climate change combined with the expansion of built-up areas increases the vulnerability of urban areas to flooding and economic damage. The results also reveal that the impacts of climate change will increase the total damage from floods by $26 \%$. However, appropriate flood mitigation will be helpful in reducing the impacts of losses from floods by approximately $8 \%$ with the restoration of lakes and by approximately $29 \%$ with the implementation of water-sensitive urban design (WSUD). This study will be useful in helping to identify and map flood-prone areas at local and regional scales, which can lead to the detection and prioritization of exposed areas for appropriate countermeasures in a timely manner. In addition, the quantification of flood damage can be an important indicator to enhance the awareness of local decision-makers on improving the efficiency of regional flood risk reduction strategies.
\end{abstract}

Keywords: flood damage; flood risk; climate change; future assessment; flood controls

\section{Introduction}

Disasters are considered a substantial problem to the functioning of society. They can be classified into natural and human-induced disasters [1]. Natural disasters are caused by a natural hazard, such as a geophysical, meteorological, hydrological, or climatological hazard, and its magnitude depends on meteorology, topography, etc. Additionally, the occurrence of natural disasters is expected to increase due to global warming, which may lead to significant negative economic growth in poor countries in particular [2]. Over the past 30 years (1986-2015), approximately 470 natural disaster events occurred, and the average overall losses were estimated at Dollar US (USD) 126 billion and are continuously increasing [3]. Indeed, in 2016, natural disaster losses increased compared to the averages 
from previous decades, up to USD 175 billion [4]. Climate change may contribute to the frequency and intensity of extreme weather and climate events [5]. In past decades, natural disasters, such as flooding, have become more common and more severe. Flood hazards induce catastrophic and severe consequences to affected people and national economies. The impacts can be divided into three categories: social, economic, and environmental effects [6]. The effects of climate change and of unplanned urbanization on developing countries, in particular, are the main drivers resulting in the increase in the frequency and strength of urban flood disasters [7]. Future climate change can also result in increases in flood damage [8]. The increase in potential damage and the vulnerability of people has led local decision-makers and governments to adopt and to implement flood control to attenuate disasters in urban areas. International communities are also interested and aware of the risk of natural disasters. Accordingly, three international frameworks, namely, Sustainable Development Goals (SDGs), the Paris Agreement on Climate Change, and the Sendai Framework for Disaster Risk Reduction, were adopted in 2015. In addition, many institutions, such as public agencies, insurances companies, and academia, in many countries generate and apply flood damage models to assess the expected economic flood impacts [9]. In fact, the assessment of flood damage is characterized by a degree of uncertainty [10]. Uncertainties are mainly associated with flood risk assessments [11]. For this reason, risk-based approaches have recently been applied in flood management $[10,12]$. Indeed, flood risk is identified as the damage due to inundation that is exceeded by a given probability [11]. Moreover, the quantification and the valuation of flood damage are significant factors to take into account for decision-making strategies about specific flood risk management measures. Additionally, flood losses are estimated to support policy analysis and flood insurance [13]. Damages from floods can be classified as both tangible and intangible damages and direct and indirect damages [14]. Tangible damages can be measured in monetary terms, but intangible damages cannot be directly measured. Direct damages are mainly due to the physical impacts of the hazard. Flood impacts can cause damage to or failure of buildings [15]. However, the impacts on national economies and business interruptions can be related to indirect damages. Several tools and parameters have been developed and applied to accurately estimate flood losses. In cases of direct flood damage estimation, the flood depth-damage function is the most accepted and applied approach. It is used to predict direct or physical flood damages [16-18]. This function represents the relationship between expected loss and flood water depth [19]. Other models, such as Flood Loss Estimation MOdel for the private sector (FLEMOps), Hazards U.S Multi-Hazard (HAZUS-MH), or Flemish model, are also used to estimate flood losses and to simulate tangible damage in particular. These models are characterized by the scale of application and their inputs. As an example, FLEMOps is mainly related to the estimation of the direct loss of residential buildings and household contents while taking into account water levels and buildings [20]. However, the HAZUS-MH software includes three types of models (earthquake, wind, and flood). This software is used in the U.S., and it requires several types of input data to estimate the direct tangible damages and indirect damages [21]. Recently, some researchers determined flood risks and damages at a large scale with the application of geographic information systems (GISs) [22-24]. Indeed, a GIS is a useful and an effective tool for risk analysis and mapping flood risk areas [25]. In addition, free and open-source software for modeling flood risk has also been developed and it can be easily applied by stakeholders to establish efficient mitigation strategies [25,26]. Flood risk assessment is also important to estimate the benefit of flood mitigation strategies and to quantify residual risk [27]. The identification of flood hazard areas will contribute to prioritizing risk prevention measures to optimize investments [23]. Flood hazard mapping can also be used to conduct more efficient and sustainable flood risk management useful for current flood protection and for future generations. Indeed, the implementation of structural and non-structural measures to mitigate flood risks can be sustainable strategies.

Due to various factors, Asian regions are considered the most exposed areas in the world to flood hazards. The occurrence of natural disasters has risen considerably, and the risk of natural disasters in Asia is higher than in Europe and Africa. Between 1980 and 2009, an estimated 38\% of global economic losses attributed to natural disasters occurred in Asia [28]. Different studies have focused on flood damage, but only a few have emphasized future assessments considering the impacts 
of climate and land-use changes. For this reason, it will be valuable for the local policy-makers to have efficient tools to predict the future impact of climate and land-use changes on urban flooding damage. The main objective of this research is to estimate future urban tangible direct flood damage in Hanoi using an approach based on the integration of hydrologic and economic data in geographic information systems (GISs). The impact of flood risk management will also be assessed in this study by an analysis of the scenarios related to the implementation of structural and non-structural flood protection measures. Indeed, the paper is organized as follows. Section 2 introduces the study area and describes in detail the methodology and data applied for the analysis. In this section, flood risk and damage components used for the assessment are presented. The main results related to flood risk and damage are proposed and discussed in Section 4 . The paper concludes with a conclusion section to emphasize the efficiency of the outcomes and future analysis.

\section{Materials and Methods}

In this research, a spatial analysis approach is applied to assess future urban flood damage in the To Lich River watershed in Hanoi. Specific parameters and datasets were used and integrated into a GIS to determine the flood conditions in 2015 and 2030 at river basin scale. This approach, which is used to evaluate the total direct tangible flood damage, required several data types, such as satellite images, topographic data, soil characteristics, property prices, and flood damage rates. Figure 1 shows the flowchart of the methodology. These parameters and components applied for the assessment of flood damage were mainly converted to raster format with a cell size of $60 \times 60 \mathrm{~m}$ and georeferenced to WGS1984 UTM Zone 48N. However, the implementation of appropriate measures can be a solution to reduce the effect of flood hazards and to protect people and buildings. For this reason, in this study, simulations of the implementation of adaptation measures were also performed. In this study, ArcGIS 10.4.1 was used for data processing and analysis.

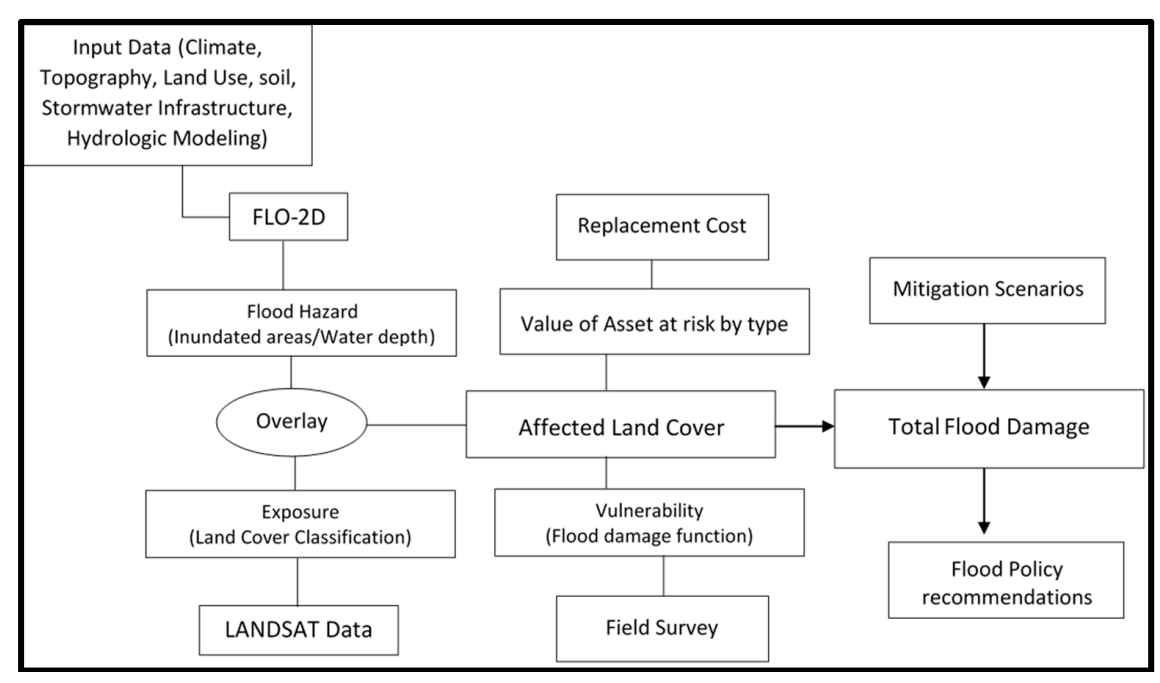

Figure 1. Flowchart of the methodology.

\subsection{Study Area}

Hanoi is located in the northwestern area of the Red River Delta. After the expansion of the administrative boundary in 2008, the area is now $3358.9 \mathrm{~km}^{2}$, and it contains urban and rural districts, towns, wards, and communes [29]. The climate is characterized by hot summers and rainy and cold winters. The river network in Hanoi is dense and considerable, and it includes the Red River, the Day River, and the Nhue River; many ponds and lakes are also located in the city [30]. In 2015, its population was 7,328,400 (density, 2182 person $/ \mathrm{km}^{2}$ ), and it is continuously increasing [31]. Due to its geographical location and features, Hanoi as well as almost all Vietnamese cities are prone to flooding. 
Topographic conditions are low and flat, with the ground level being lower than the high-water levels of the rivers and channels, which contributes to the increased risk of floods in Hanoi. The To Lich River, which flows inside central Hanoi, was selected as the study area to assess the impact of floods in urban areas in Hanoi (Figure 2). The watershed mainly covers the urban area and in particular old Hanoi. The area of the catchment is approximately $113 \mathrm{~km}^{2}$. The study area is located between $21^{\circ} 2.704^{\prime} \mathrm{N}$ and $20^{\circ} 55.462^{\prime} \mathrm{N}$ latitude and $105^{\circ} 47.009^{\prime} \mathrm{E}$ and $105^{\circ} 52.231^{\prime} \mathrm{E}$ longitude. The area covers many districts in Hanoi, which can increase the vulnerability for people and infrastructures.

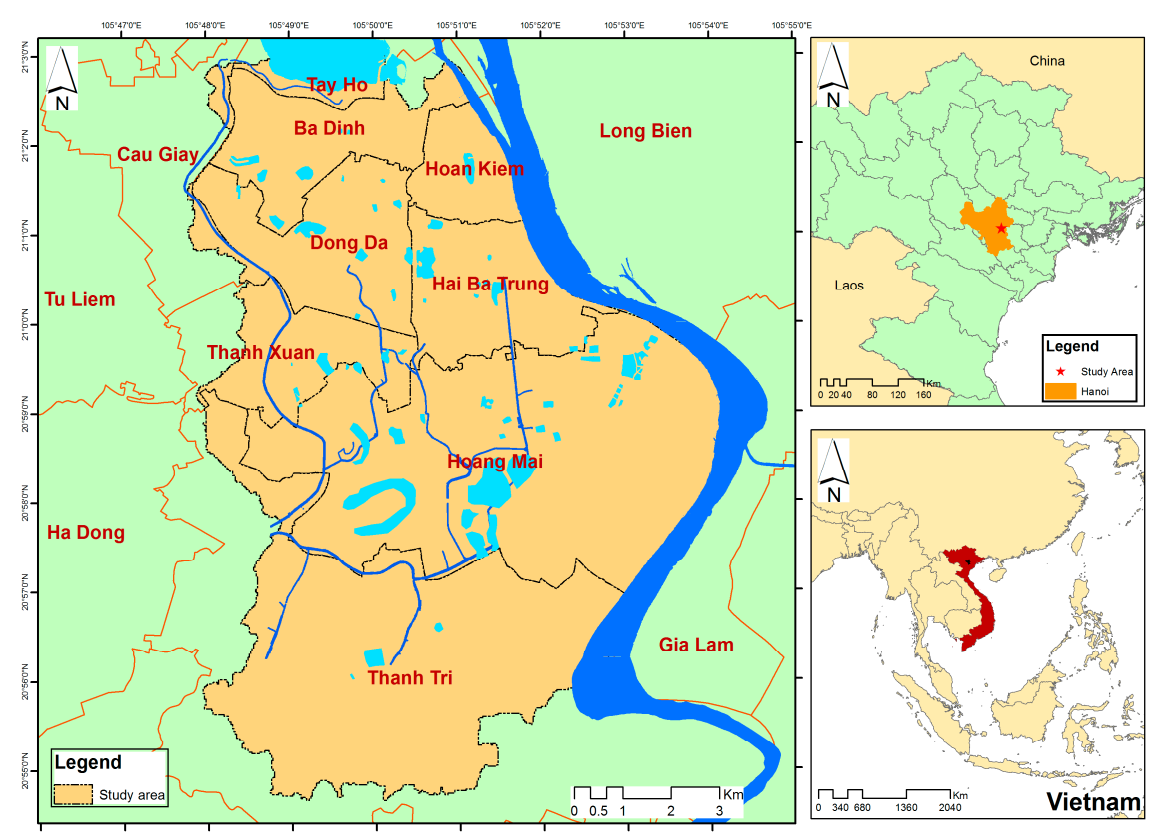

Figure 2. Study area location.

\subsection{Flood Risk Assessment}

Flood risk is defined as the probability that a loss will occur [31]. The accuracy of an assessment of flood risk depends on information related to three main components: hazard assessment, exposure, and vulnerability [32,33]. Furthermore, the evaluation of the expected annual flood damage is linked with an exceedance probability [34]. The approach applied is based on spatial analysis, and all inputs are converted to a grid with a $60-\mathrm{m}$ pixel size.

\subsubsection{Flood Hazard}

This component is mostly related to inundation characteristics, such as area, depth of water, velocity, and duration. In this study, water depth is applied as the main factor in the flood hazard assessment. Duration and velocity are not included in the analysis. Moreover, the simulation of flood characteristics, such as peak discharge and flood inundation, is obtained through computer and mathematical models, which can be grouped into one-dimensional (1D), two-dimensional (2D), and three-dimensional (3D) models [35]. These models are widely applied in urban areas because they can contribute to the representation and the simulation of the physical situation that can occur during floods [36,37]. For this research, FLO-2D was selected to simulate flood inundation for the current and future climate, corresponding to a 50-year return period. FLO-2D can generate the temporal change in the flow depth, flow velocity, and affected areas [38]. Several data are employed to simulate floods, such as a digital elevation model (DEM) with a $30 \mathrm{~m}$ resolution, soil type from the Food and Agriculture Organization (FAO), and land-use data derived from Landsat satellite images [36]. The DEM represents the land elevation data, which are crucial for estimating the storage volume of surface flooding. Hence, the quality of the output depends on the quality of the DEM. However, 
time of simulation, which largely depends on cell size, computer system efficiency, size of modeling area, level (scope) of study, and several other parameters, should be also taken into account while defining the cell size of the flood inundation simulation. These factors were considered in determining the grid size of $60 \mathrm{~m}$ for the flood inundation simulation, although a higher spatial resolution (5 to $20 \mathrm{~m}$ ) is suggested for a detailed flood inundation simulation study. Loss of flood storage due to buildings and other urban features can be graphically assigned using individual or polygon grid element selection. In this study, the "Area Reduction Factor" (ARF) is used to indicate storage loss caused by buildings. This command enables us to compute the blockage using a polygon shapefile of a built-up area.

For the future simulation, climatic variables are applied to predict the change in flood hazards from global warming. Global Climate Models (GCMs) indicate that increasing greenhouse gas concentrations will have an important implication for the climate at global and regional scales [39]. For a more accurate climate change analysis, different GCMs are integrated into the model. For the climate change impact assessment, daily precipitation outputs from an average of three GCMs (MRI-CGCM3, MIROC5, and HadGEM2-ES) and two representative concentration pathways (RCP), 4.5 and 8.5, were employed. Due to the great amount of uncertainty associated with the scenarios and projections (the 50-year daily maximum rainfall was estimated as $416 \mathrm{~mm}, 297 \mathrm{~mm}$, and $411 \mathrm{~mm}$ for RCP4.5 and $412 \mathrm{~mm}, 593 \mathrm{~mm}$, and $411 \mathrm{~mm}$ for RCP85 for the MRI, MIROC5, and HadGEM2-ES GCMs, respectively, over the Hanoi region), the use of multiple GCMs is recommended to provide the range of recommendations for addressing various climate change impacts. The quantile-quantile bias correction technique was applied to downscale or minimize the biases in the GCM data. Gumbel frequency analyses were conducted to estimate the 1-day maximum precipitation for the current and future flood assessments. The flood hazard was calibrated and validated using a 2008 flood event, which occurred in Hanoi between 30 October and 3 November 2008. The model parameters were adjusted by comparing the observed and simulated inundation depths at multiple locations. The roughness coefficient was adjusted to fit the simulation results with observations by applying a "trial and error" procedure. A range of roughness coefficients were tried for different land use classes. An overall value of 0.04 was allocated for the Manning's roughness parameter. The simulation time for the inundation modelling was $48 \mathrm{~h}$, which accounted for the modelled 1-day maximum precipitation of the 50-year return period floods, and the output time step was $1 \mathrm{~h}$.

\subsubsection{Exposure}

The exposure component represents the element at risk, and it is mainly linked to land-use land cover (LULC). Remote sensing products are used to produce suitable LULC maps. Remote sensing provides adequate tools to assess spatial and temporal land-use changes [40]. In this research, two satellite images of our study area are employed as described in Table 1. Level 1 Landsat images were downloaded from https: / / earthexplorer.usgs.gov/. Prior to image analysis, appropriate data processing, such as band composites and clipping, was completed. In addition, Landsat 5 of 2007 and Landsat 8 of 2016 were not only used to establish LULC maps useful for the current flood simulation but also used to predict the LULC of 2030. The land change modeler (LCM) for ArcGIS Software Extension 2.0 was operated to predict the land-use pattern based on the previous change trend (Figure 3). The LCM was developed by Clark Labs, Clark University [41]. In this work, a Markov Chain and logistic regression were applied to determine the suitable spatial configuration considering particular driver factors. The DEM and slope are the main driver factors, which were applied to influence change allocation.

Table 1. Satellite images applied.

\begin{tabular}{ccccc}
\hline No. & Path/Row & Data Set & Acquisition Data & Cloud Cover \\
\hline 1 & $127 / 045$ & Landsat 5 TM C1 Level 1 & $08 / 05 / 2007$ & $7 \%$ \\
2 & $127 / 045$ & Landsat 8 OLI/TIRS C1 Level 1 & $01 / 06 / 2016$ & $13 \%$ \\
\hline
\end{tabular}




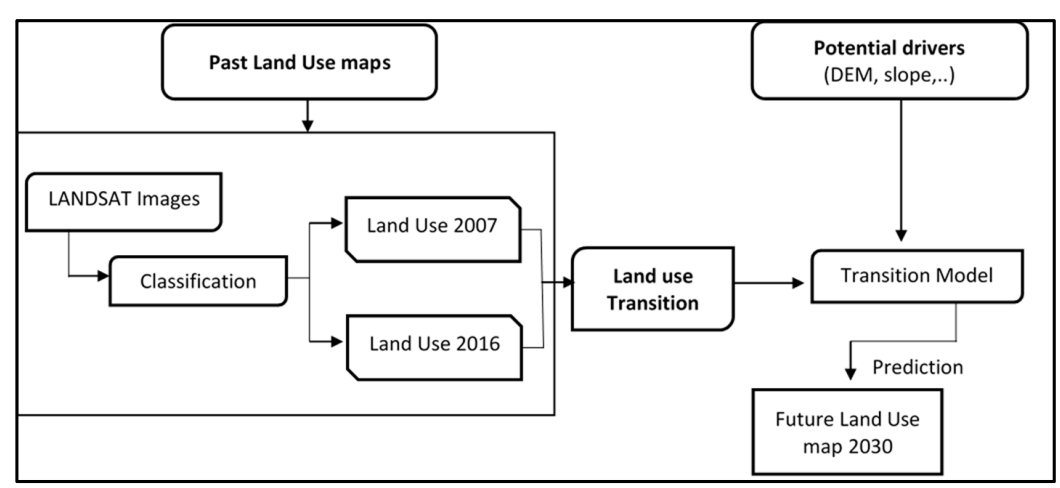

Figure 3. Land-use change approach. DEM: digital elevation model.

The two previous satellite images were classified using the supervised classification maximum likelihood algorithm with the ArcGIS software and validated. Landsat sensors have a moderate spatial resolution of $30 \mathrm{~m}$. With this resolution, it was quite difficult to distinguish individual houses or buildings and to establish a detailed land-use map. However, it was clear enough to distinguish urban growth for a regional coverage. Therefore, four classes, namely, built-up, water bodies, agriculture land, and green land, were identified based on the supervised classification. To measure damage in monetary terms, data about the value of assets at risk were integrated into the analysis. The value of assets can be indicated as the replacement cost or depreciated/repair cost [25]. This value was estimated based on the assumption that damaged assets have to be replaced by a similar object [33]. In this study, the values of the built-up class were expressed as replacement costs of residential and non-residential buildings. The infrastructure damage was added into the analysis by the application of weighing factor approaches [9-42]. Consequently, it was assumed that infrastructure losses are in proportion to total residential losses. The average unit property value $\left(\mathrm{VND} / \mathrm{m}^{2}\right)$ by district from the residential and non-residential sectors that was applied in the analysis was based on the 2015 constant price [43]. These prices were converted from Vietnamese Dong (VND) to US Dollar (USD). In addition, the damage of agricultural land was mainly estimated based on the loss on productivity. However, other land-use classes, namely, water bodies and green land, are not considered in the calculations. Indeed, the land use layer was overlaid with flood hazard data to identify affected areas in the GIS environment. The generated output was useful to evaluate the flood depth damage function as an indicator of vulnerability.

\subsubsection{Vulnerability}

Vulnerability assessments provide information on how elements at risk are being harmed by flooding [44]. In this study, the indicator of vulnerability was evaluated based on the susceptibility of exposed assets to contact with water. The susceptibility of the element at risk is assessed by the establishment of the flood-depth damage function [32]. Two methods are used to generate the flood damage function. The first method produces the function from the losses following flooding. The second method is called the synthetic flood damage function. In this case, the function is established from detailed inventories of the types of land use and potential losses [19]. In this study, the flood depth damage function is derived from data collected from field surveys. A regression analysis is applied to obtain this function. The dependent variable is the direct damage percentage, and the independent variable is flood depth. The depth of flood has a related impact on the damage it causes. This correlation can be a relevant way to construct the flood depth damage function based on a past flood event. Indeed, the flood damage function is an important component of direct flood estimation. In this work, the flood damage depth is constructed as a logistic function with two parameters (Equation (1)), which is developed from XLSTAT software.

$$
Y=\frac{1}{\left(1+e^{(-p r 1-p r 2 \times X)}\right)}
$$


$Y$ : dependent variable, damage factor; $X$ : independent variable, flood depth; $p r 1$ and $p r 2$ are parameters of the function.

The collected data from the survey were used to establish this function for buildings in residential and non-residential sectors and consequently to estimate the flood damage rate. As it was described in exposure section, the land-use layer used in this work is coarse, which makes it difficult to distinguish in detail the buildings for the current situation and to predict the future condition. For this reason, the analysis was not based on a single object and the flood depth damage function was applied for a grouped class, namely, built-up. Moreover, the same value of the assets was employed by district. In the study area, the majority of buildings are in concrete. Therefore, materials of construction were not included in the analysis of vulnerability and the establishment of the damage function.

\subsection{Scenarios Analysis}

There are a number of measures used to reduce the risk of a hazard and to protect people, private and public buildings, and infrastructure. However, the best approach considering risk reduction measures should combine five stages: inherent safety, prevention, detection, control, mitigation, and emergency response [1]. Interventions are classified into hard and soft measures [45]. In the case of Hanoi, the local government improved flood defenses by the construction of the Yen So pumping station, and the capacity increased to $90 \mathrm{~m}^{3} / \mathrm{s}$. To enhance the efficiency of flood risk reduction and to limit the size of the hazard, two scenarios based on an implementation of blue and green infrastructure (BGI) are simulated. Retaining the water for infiltration or preserving water bodies for flood storage is a better alternative instead of constructing larger pipes. The Hanoi Drainage Plan 2030 ensures a long-term vision for Hanoi through the plan to provide a "green space". The Hanoi Drainage Plan will pay special attention to preserving and developing this characteristic following ecological and modernized criteria. The main advantage of BGI is that it can contribute to protecting not only the city but also the environment. The first scenario is based on the protection and restoration of lakes and ponds. It was assumed that the flood storage was 8 million cubic meters based on the preservation/regulation of lake/ponds with an area of $4 \mathrm{~km}^{2}$ and a depth of $2 \mathrm{~m}$. The second scenario dealt with the setup of water sensitive urban design (WSUD) combined with lake preservation. The assumption of the WSUD option is an increase of $40 \mathrm{~mm}$ (about 10\% of total rainfall) infiltration for extreme rainfall events. As precise details on the location of lakes or infiltration trenches/boxes were not available, the additional infiltration losses or storages in lakes were uniformly distributed over the inundation area.

\subsection{Field Survey}

A field survey was conducted at the ward level during March 2017. Interviews were conducted with local people in affected residential and non-residential areas using specific questionnaires. Potential respondents were selected from the flood hazard map generated and calibrated based on the 2008 flood event. The flood map was also helpful for dividing the target population into common groups/classes. During the survey, a global positioning system (GPS) unit was used to determine the exact location of selected classes, and then a population for each group was chosen and interviewed randomly. The main purpose of the field survey was to collect data about the situation during the 2008 flood and to determine the perceptions of the people regarding flood risk management. A face-to-face technique was employed to collect data from interviewees. The questionnaire used during the survey was composed of three main parts: Part I: household characteristics; Part II: flood risk/damage; and Part III: flood risk management measures. In Part II, the questions are mainly related to the 2008 flood event, which was helpful to determine the relationship between the impacts on properties at risk and flood characteristics and then to establish the flood depth damage function. However, Part III is associated with the perception of local people on flood risk reduction. Two hundred and ninety-three (293) responses were collected from residential and non-residential sectors. The main objective of the survey was to establish the flood damage depth function of buildings 
from the relationship between flood damage and flood depth. For this reason, the questions are mainly related to the 2008 flood event.

\section{Results and Discussion}

Flood depth and damage were evaluated at a grid cell scale to monitor the flood risk in the urban watershed. Hazard maps are generated and classified based on the level of inundation and water depth. However, damage maps depend on the impact of depth to losses. The total damage is obtained from the analysis of three components: flood hazard, exposure, and vulnerability.

\subsection{Flood Hazard Simulation}

The model parameters were calibrated based on the comparison of the observed and simulated flood characteristics from the 2008 flood event. This event was selected primarily due to the heavy rainfall with a return period of more than 50 years. In addition, the results show that inundated areas are increasing from the northern part to southern area of the city and from east to west. The most inundated district in the watershed was the Thanh Tri District. This situation can be explained by topography and land characteristics, which are mostly lower in the south. These findings are confirmed by the work of Nguyen et al. (2013) [46], who found similar results in their research on Hanoi City. In addition, it was identified through the analysis of the satellite images developed by UNOSAT that the southern areas were the most inundated areas during the 2008 flood event. Additionally, high flood hazard areas are detected along the river. Similar results are generated by Bathrellos et al. (2017) [47] in their study. They found that the high and very high flood hazards are located along the principal stream of the Xerias drainage system. Moreover, the comparison between the current and future scenarios in 2030 showed that the inundated areas and depth increased, as presented in Figure 4. However, the effect of climate change simulated with a $23 \%$ increase in rainfall in 2030 indicated that $19 \%$ of inundated areas with a flood depth of more than $0.5 \mathrm{~m}$ will increase in the future. Additionally, other districts, such as Hoang Mai, Thanh Xuan, and Ba Dinh, will be more prone to floods. In fact, the climate change scenario revealed an increase in rainfall, which may lead to an increase in inundated areas. This result corroborates the findings of (Arnell and Gosling, 2016) [48]. These authors evaluated the future scenario of flood risk based on climate models and socioeconomic data.

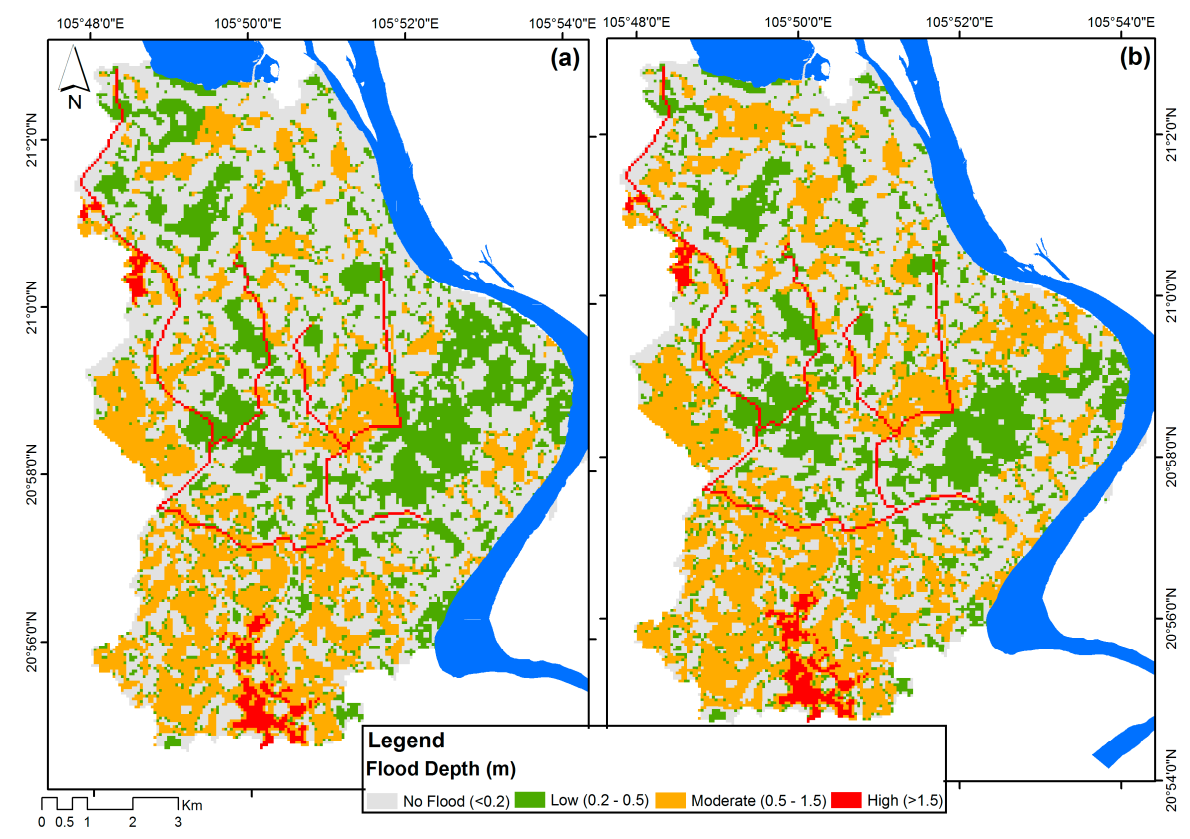

Figure 4. Comparison of inundation depth map between scenarios with and without climate change (a) Current situation and (b) Future situation with climate change. 
The impact of variability of climate was assessed to identify and to determine the spatial extent of areas at risk. In fact, mapping the spatial distribution of risk will provide significant information for integrated flood risk management. Indeed, areas at high risk should be prioritized [32].

The increase in frequency and magnitude of floods in urban areas is due to the suppression of streams and ponds [49]. For this reason, the coping mechanisms implemented to mitigate floods are based on the preservation of lakes and the enhancement of infiltration. The findings in Figure 5 indicate that inundation areas will attenuate the effects of the flood measures even under climate change conditions. Additionally, the comparison between the current situation and scenarios based on lake preservation and the setup of WSUD shows a reduction in inundation areas by $17 \%$ and $59 \%$, respectively.

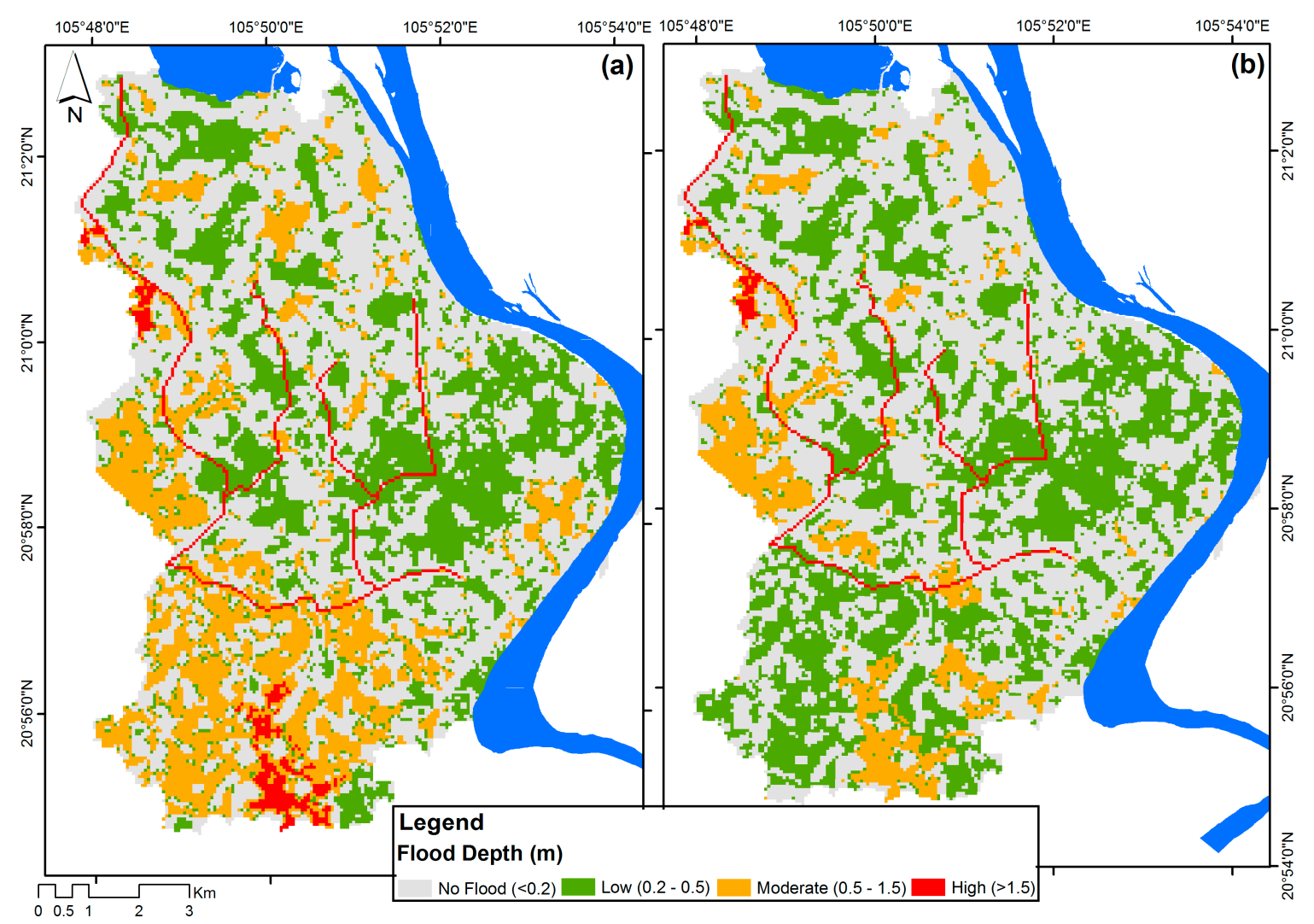

Figure 5. Inundation maps with implementation of flood mitigation and climate change effects. (a) Lake preservation and (b) combined measures (water sensitive urban design (WSUD) and lake).

As a result, it was observed that flood depth and the extent of inundation areas are the main consequences of climate change. However, mitigation measures can be conducted to reduce the effect of flooding by decreasing the flood depth level and limiting the affected areas, as illustrated in Figure 6. Although there are several relevant flood characteristics, such as maximum water depth, flood duration, and flow velocity, only water depth is used in the flood damage modelling [13,50]. Therefore, in this study, water depth is considered to be the main parameter for the flood damage assessment. Moreover, the production of a flood hazard map with the impacts of climate change and the consideration of the contribution of flood controls will provide useful information about flood risks and will help to assess potential vulnerabilities, such as physical vulnerability or economic vulnerability [1]. 


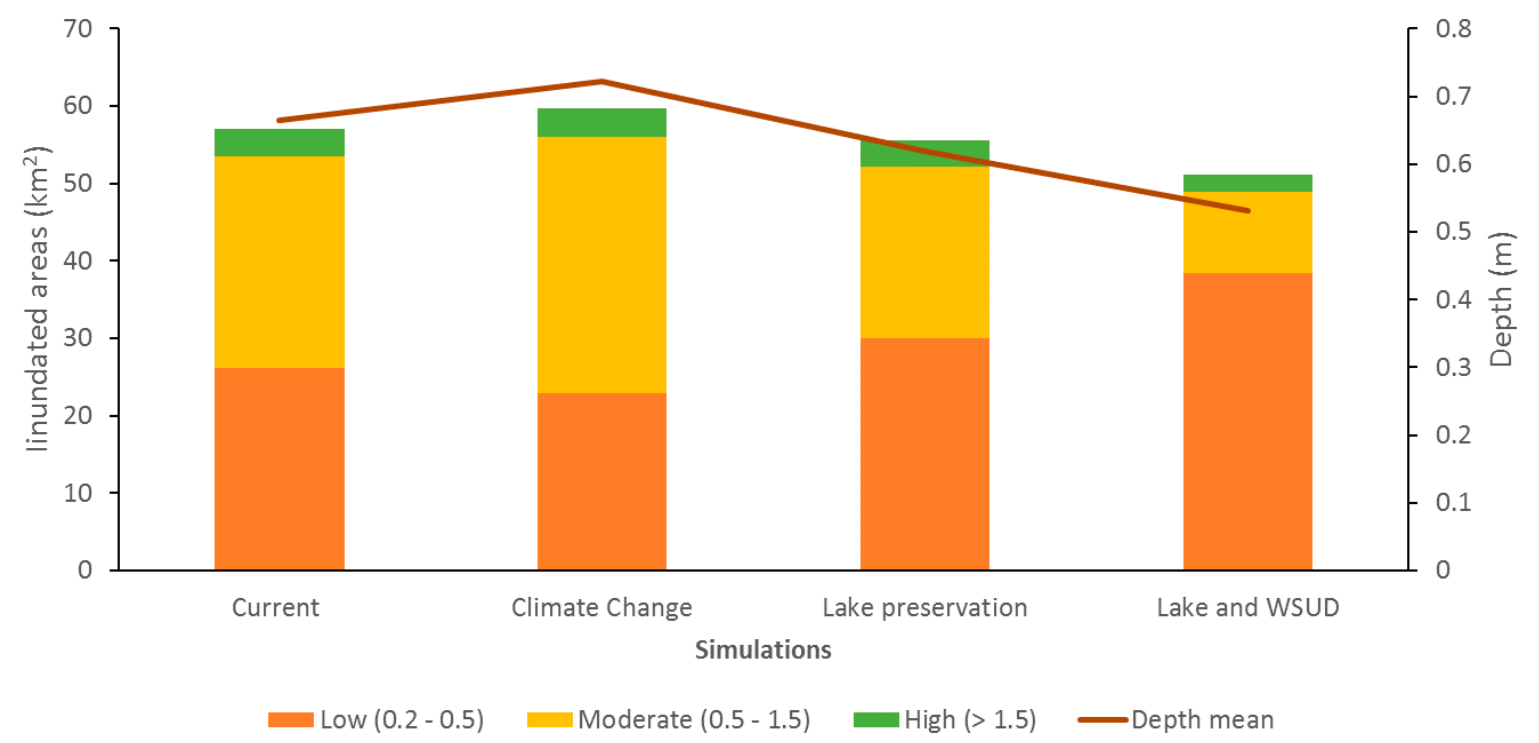

Figure 6. Comparison of flood hazard characteristics.

\subsection{Land-Use Land Cover Change}

The future land use in 2030, derived from two past satellite images, showed an increase of built-up areas by approximately 7\% (Figure 7). In fact, the dynamic economic growth in Asian megacities can lead to rapid urbanization with its negative and positive consequences. Actually, the expansion of cities in appropriate locations may contribute to extend the exposure of buildings and infrastructures to a high flood threat [51]. People looking for a better life migrate to cities, which results in the growth of urban sprawl in places not suitable for buildings, such as along large rivers or spaces used for floodplains. Hence, an appropriate land-use plan is required to avoid increasing the vulnerability of people and buildings. In addition, a specific flood education program can be conducted to enhance people's awareness on the negative effects of floods and it may induce them to avoid living in flood-prone spaces [52]. The comparison of urbanization in the study area between current and future scenarios demonstrated that the urban districts, such as Ba Dinh, Dong Da, Hai Ba Trung, Hoan Kiem, Thanh Xuan, and Hoang Mai, are mainly urbanized. However, Thanh Tri, as a rural district, will likely be more urbanized in the future (Figure 8).

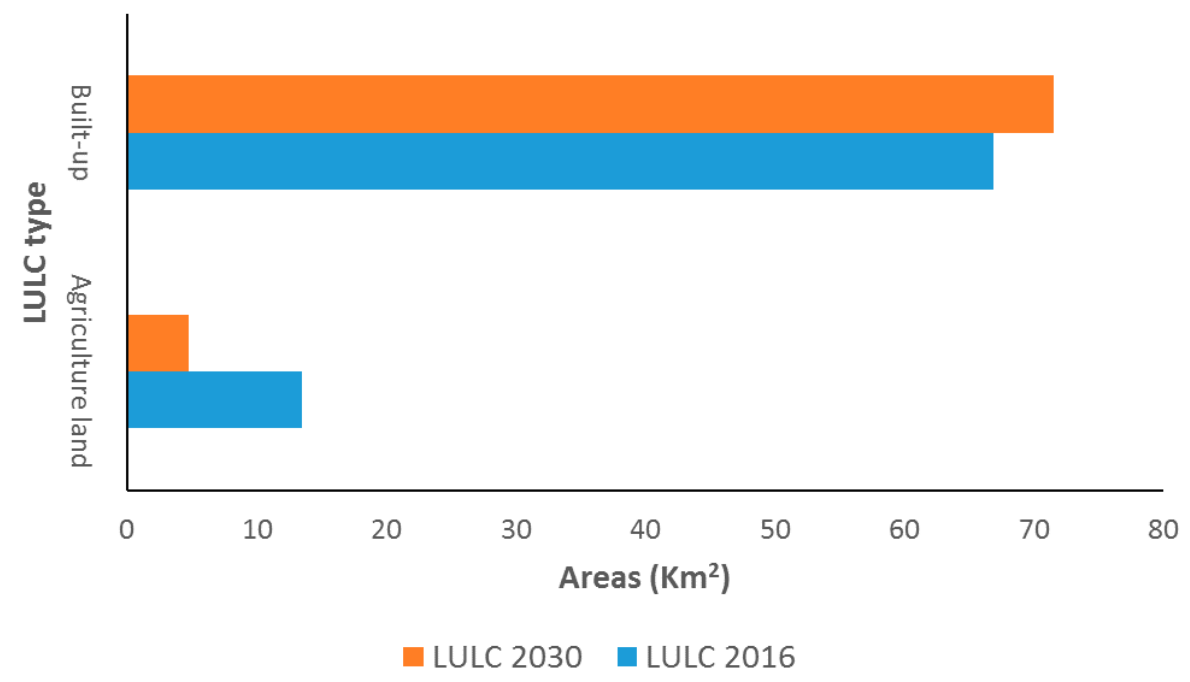

Figure 7. Land-use land cover (LULC) change in the future. 


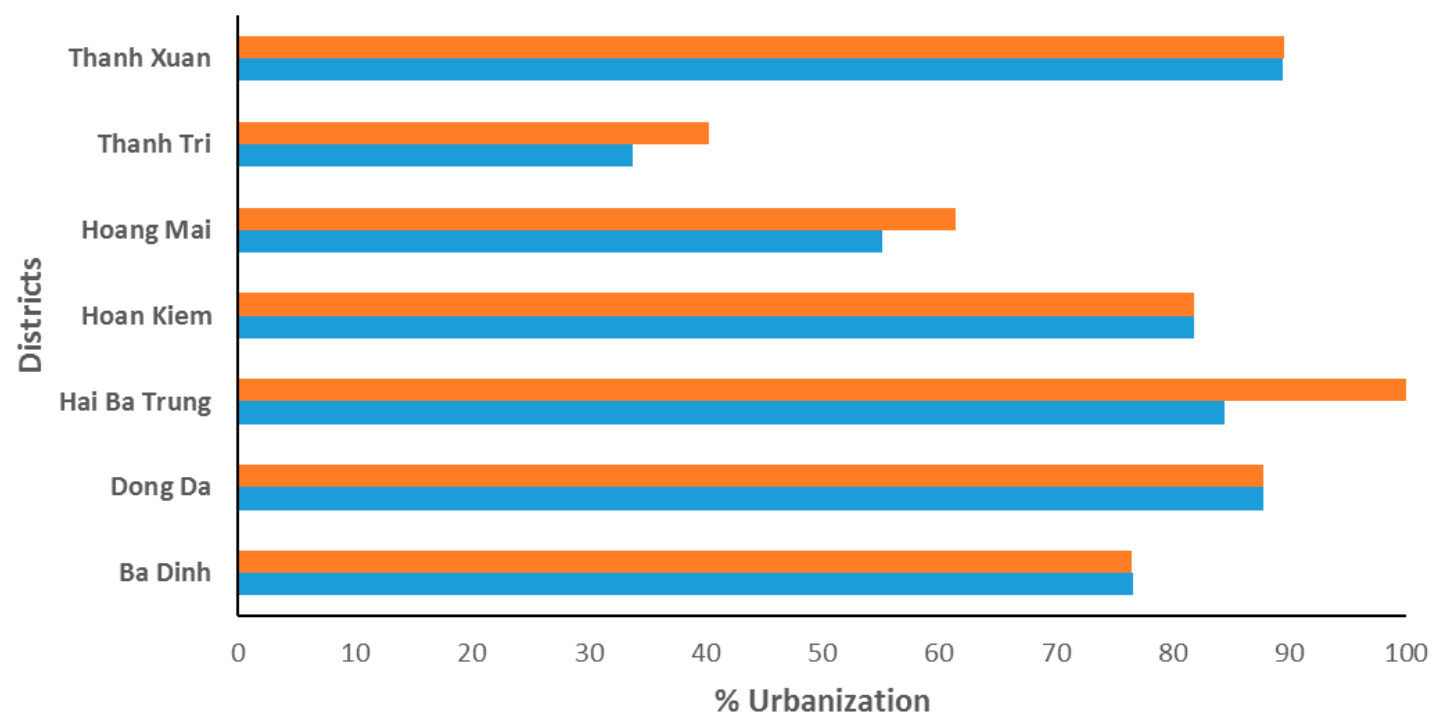

Figure 8. Urban growth by city.

In fact, urbanization changes hydrological processes within watersheds, resulting in fluctuating surface infiltration characteristics [53]. Therefore, the identification of elements at risk is very useful for flood damage assessments. In this study, the vulnerability assessment consists of the direct contact of the buildings to water. The spatial extent is an important factor for damage assessment $[17,33]$. In addition, three levels of damage analysis can be determined: macro, meso, and micro [44]. Due the low resolution of the Landsat images, the built-up class is applied as an aggregated land-use category, which includes residential and non-residential areas. Hence, our analysis is considered a meso-scale damage evaluation, which is convenient for regional analysis.

\subsection{Flood Depth Damage Function}

Vulnerability is mainly related to the flood depth damage function, which is the correlation between the flood depth and damage percentage [17,54]. In this study, this function is obtained and established from data collected from the field survey. As the main objective of the work is to assess the flood damage at the meso-scale, the same susceptibility function is elaborated for one homogenous class (Built-up). The type and material of buildings are not included in the analysis. The fitted function is illustrated in Figure 9. The statistical analysis provides a high determination coefficient $\left(R^{2}\right)$, which explains the significant correlation between water depth and damage rate. The results are shown in Table 2. This function can be considered as a significant indicator for flood damage developed for the urban area of Hanoi.

The findings indicated that damage will be more serious with an increasing depth level. At more than $2 \mathrm{~m}$, the damage will be approximately $100 \%$. This function provided a damage rate which was used for a total flood damage assessment.

Table 2. Flood depth damage function analysis.

\begin{tabular}{cc}
\hline Designation & Value \\
\hline$p r 1$ & -5.721 \\
$p r 2$ & 4.367 \\
$\mathrm{R}^{2}$ & 0.948 \\
\hline
\end{tabular}




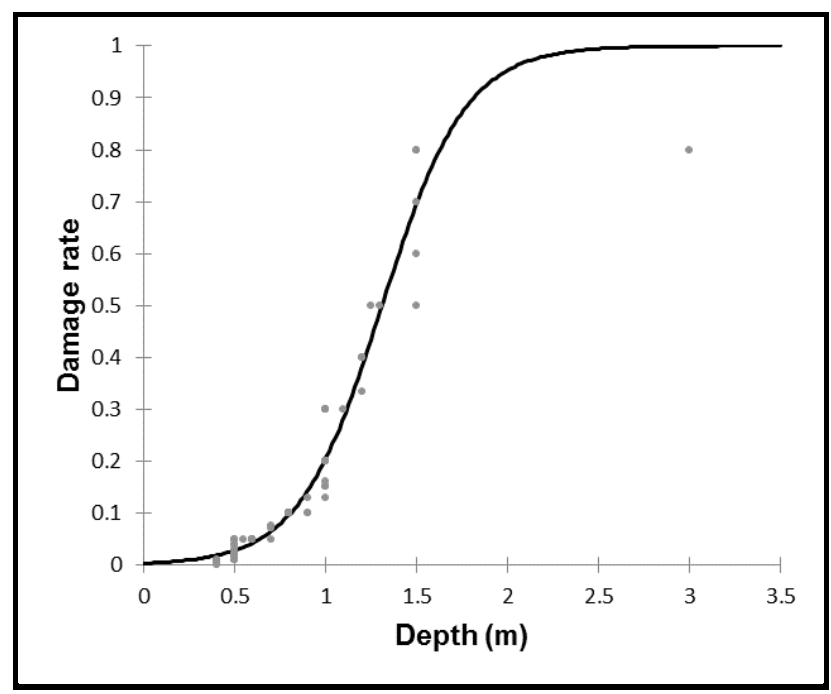

Figure 9. Depth damage function for urban areas in Hanoi.

\subsection{Damage Assessment}

Tangible direct damage is estimated in this study. The flood damage map is established with a combination of the hazard, exposure, and vulnerability components in a GIS with a grid size of $60 \times 60 \mathrm{~m}$. The calibration of the baseline results depends on the damage estimate from the Hanoi government for the 2008 flood [55]. The results obtained depicted that total damage will increase with the impacts of climate change, but flood mitigation will reduce the total damage in the study areas (Figure 10).

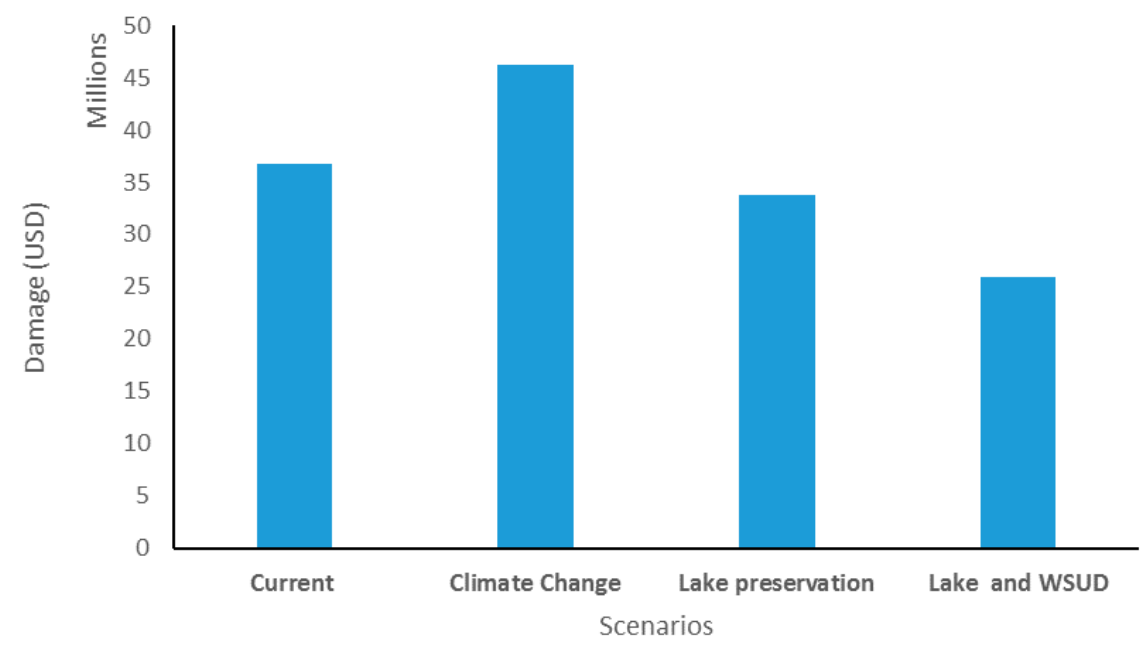

Figure 10. Total damage by scenario. USD: US Dollars.

The comparison between the current and future scenarios with and without mitigation showed a $26 \%$ increase in the total damage with the effect of climate change. In contrast, the restoration of lakes and the combined flood measures scenario will decrease flood losses by $8 \%$ and $29 \%$, respectively. The flood damage maps in Figure 11 identify that the spatial distribution of flood damage is correlated with the water depth and inundated area parameters. Damage is higher in the southern areas than it is in the northern areas of the watershed. In addition, losses in the western area are more significant than in the eastern cities. Alternatively, the implementation of flood protection measures will protect the more vulnerable regions, and then total damage will more pronounced (Figure 12). Moreover, the estimation of the total damage due to flooding in an urban area is very important for urban planning 
and decision-makers. Damage assessments are a relevant indicator for detecting the susceptibility of an area to flood risks and evaluating the advantages of implementing flood risk measures [34].

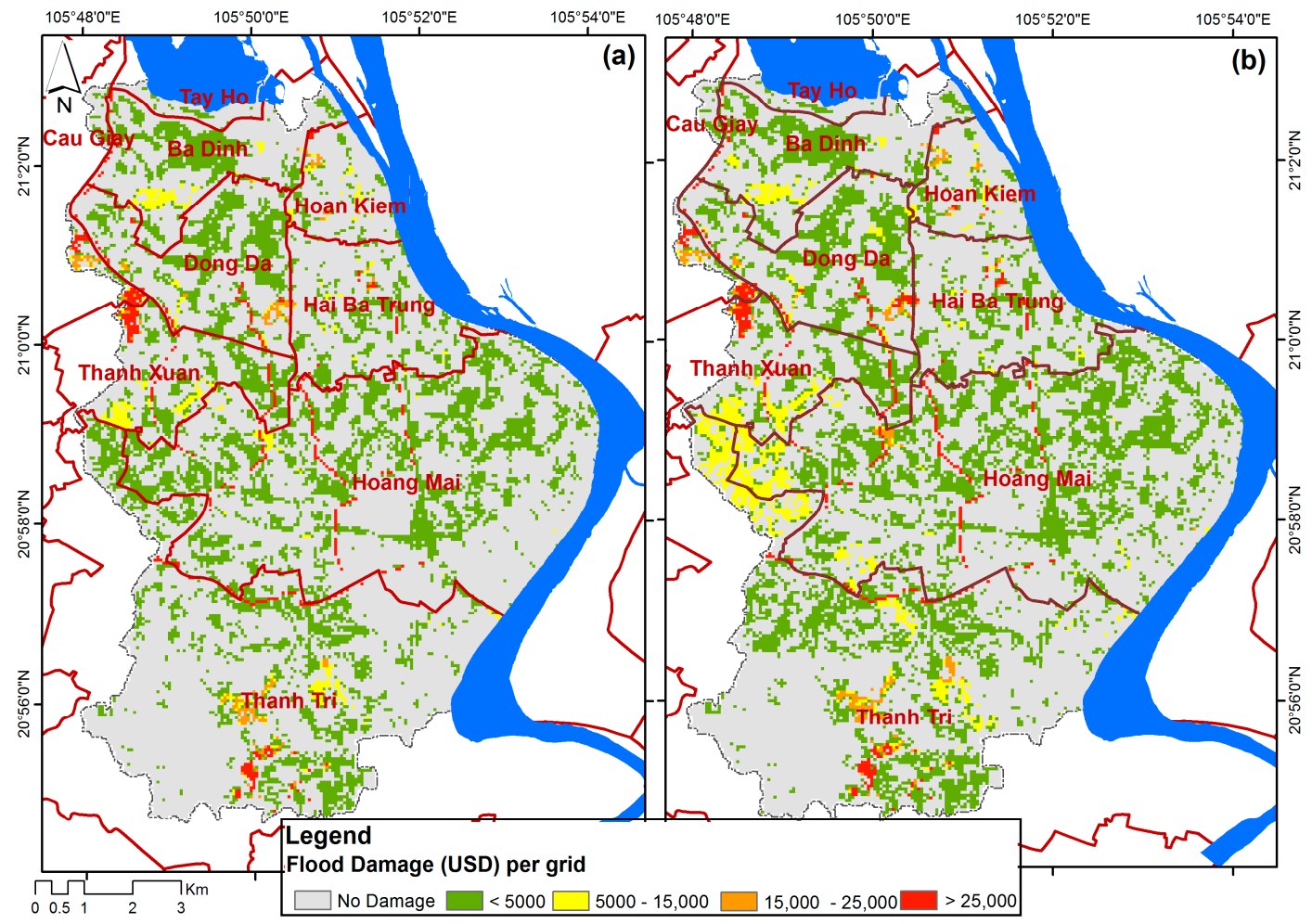

Figure 11. Flood damage map (a) Current scenario and (b) future scenario with climate change.

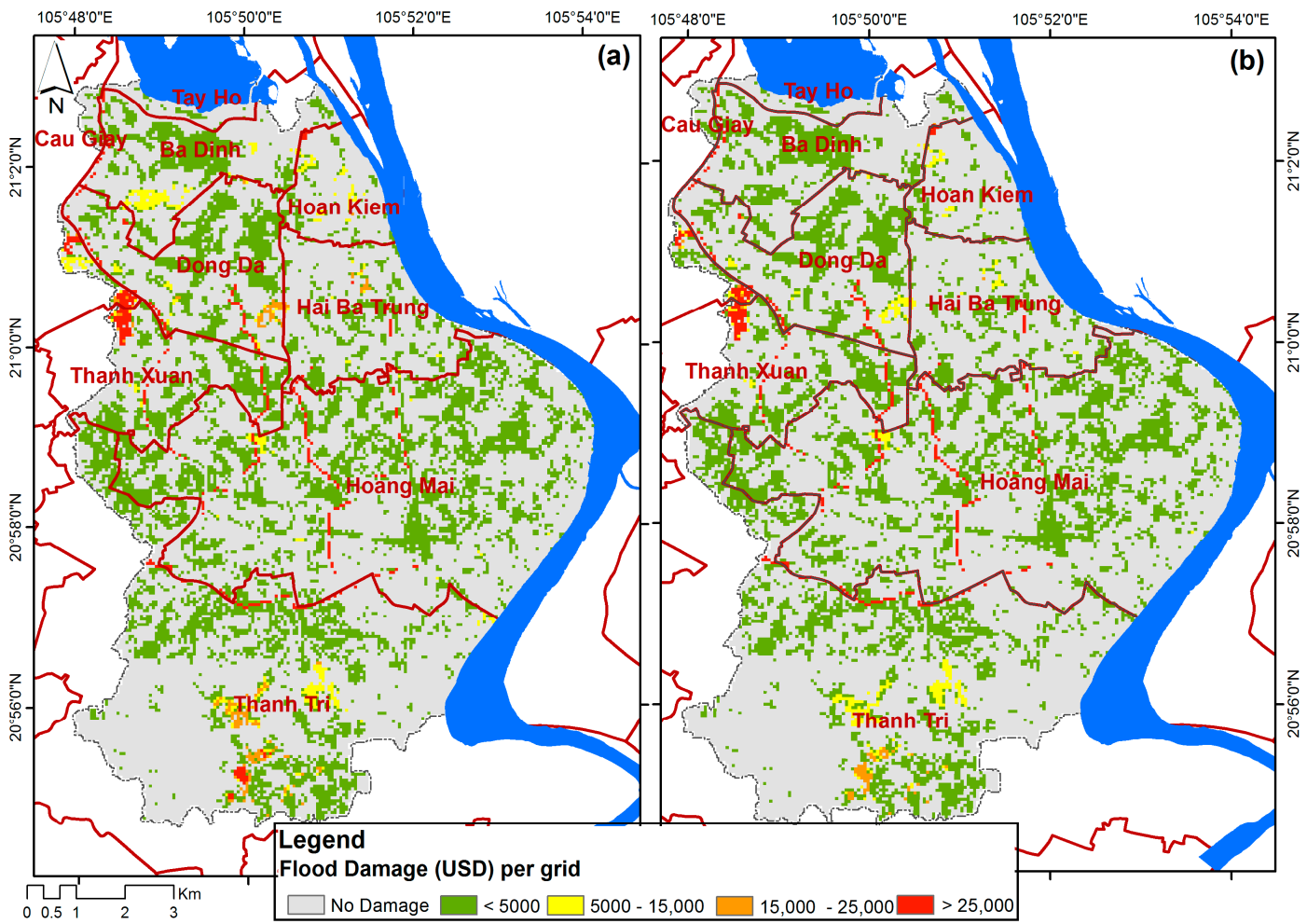

Figure 12. Flood damage map with mitigation scenarios. (a) Lake preservation and (b) combined measures (WSUD and lake). 
The analysis of flood damage in the main inundated district demonstrates that the damage will increase with the magnitude of the water depth, which is explained by our approach that is based on the application of the flood depth damage function. Figure 13 reveals that in the case of the Thanh Tri District, the total damage is not significantly correlated with the level of water depth. In fact, in this rural district, the average water depth is higher, but the total damage is still low. This result can be explained by the high degree of urbanization and the property value of the assets. Indeed, floods are a type of natural disaster that affect urban and rural areas, but their economic impacts in urban areas are more serious because the value of the assets at risk is larger [56]. In addition, due to urbanization, greenlands will be converted to impervious lands, such as roads and buildings, that will reduce infiltration and increase runoff. Consequently, the occurrence of more severe floods is increasing [57]. Regarding the value of water depth, it was observed that the Thanh Xuan and Thanh Tri districts are the main vulnerable areas to flooding because they are located in low-lying areas. Topography plays an important role in the magnitude of flooding [1]. In addition, the preservation of lakes and the improvement of drainage will contribute to reducing the damage in the inundated districts. Indeed, the combination of several measures, such as retention ponds, permeable paving, or block storage, can be conducted to reduce the peak flow and the magnitude of a flood [58].

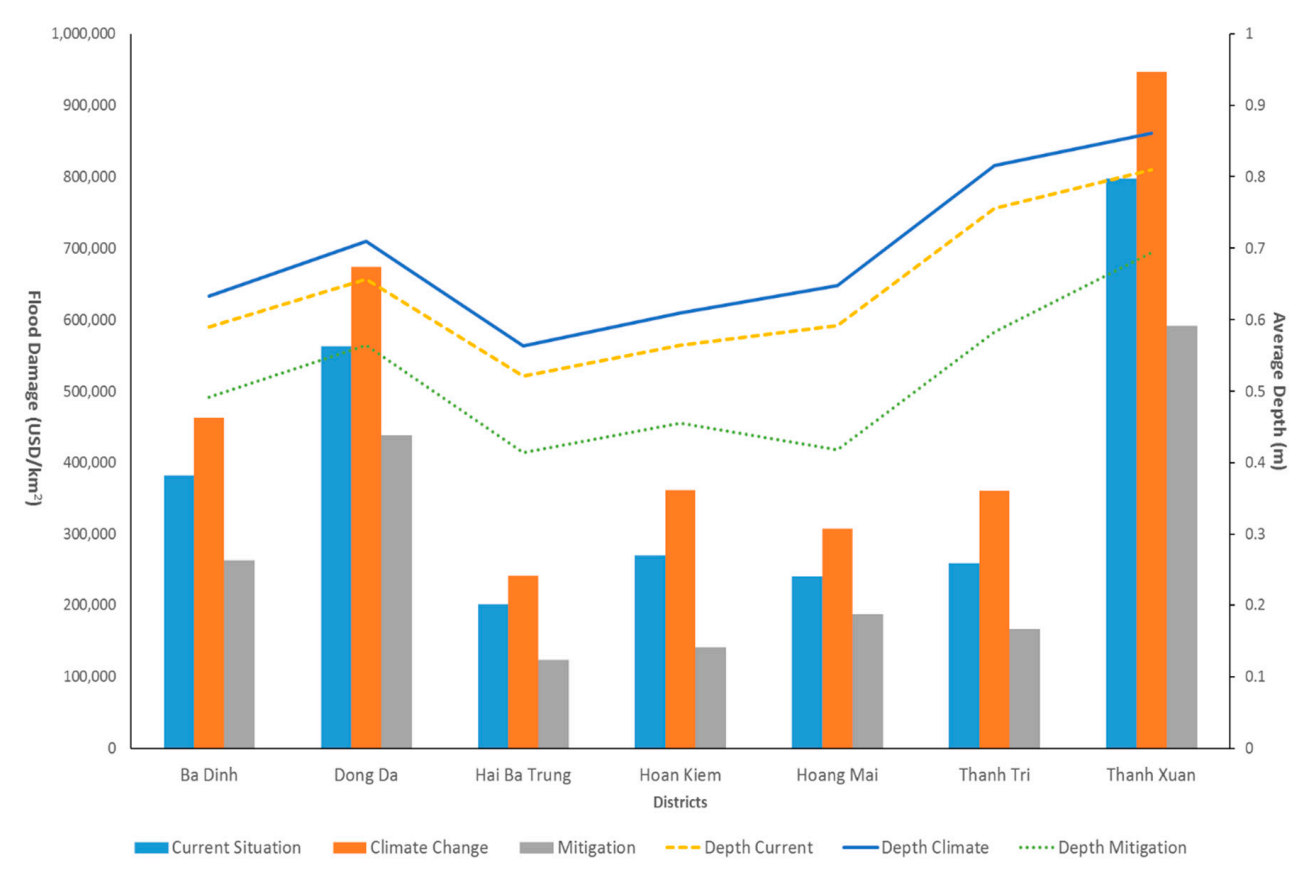

Figure 13. Flood damage by district.

Climate change combined with unplanned expansion of built-up areas increases the vulnerability of urban areas to flooding and therefore economic damage. Consequently, the adoption of appropriate flood countermeasures, as presented in this study, is required. For this reason, local decision-makers should emphasize flood adaptation and mitigation measures for sustainable urban development. Several parameters, such as climate, land-use change, and topography, should be considered for the design and implementation of suitable flood management measures. In addition, decision-makers and planners should take into account hazard maps combining physical and socio-economic factors to establish effective and suitable urban planning strategies [59].

\subsection{Perception of People}

During the survey, local people from residential and non-residential areas were requested to give their opinions about solutions to reduce flood problems. Through the analysis of data collected 
from respondents in both sectors, it was observed that local people suggested priorities to prevent and reduce the effect of flooding: 1: construction of more structural measures, 2 : improvement of the drainage system, and 3: enhancement in the efficiency of distributing flood information (Table 3).

Table 3. Flood risk reduction perception.

\begin{tabular}{cccc}
\hline No & Flood Measures & Residential (Percentage \%) & Non-Residential (Percentage \%) \\
\hline 1 & Construction of structural/hard measures & 18 & 13 \\
2 & Improvement of drainage system & 54 & 44 \\
3 & Evacuation plan & 0.5 & 6 \\
4 & Updated flood information & 18.5 & 25 \\
5 & NGO/people contribution & 6.8 & 7 \\
6 & Disaster training/education & 1.8 & 4 \\
7 & Disaster insurance & 1 & 1 \\
\hline
\end{tabular}

NGO: non-governmental organization.

Respondents believe that the drainage system is the most important flood problem. Therefore, approximately $54 \%$ and $44 \%$ of respondents from residential and non-residential areas, respectively, agreed that improvements to the drainage system can be a solution to reduce the effects of urban flooding in cases of heavy rainfall, such as in 2008. In addition, the interviewees emphasized that the enhancement of an early warning system can also be helpful to attenuate flood risks. However, people are not interested in purchasing flood insurance.

There were several reasons people noted for why they were not interested in flood insurance, such as the price, flood magnitude, or frequency, and less assistance or information. Accordingly, launching a national flood insurance program could be interesting for homeowners and small businesses. A national flood insurance program should provide insurance and maps of flood hazards and encompass regulations and incentive programs for local people to invest in flood risk reduction [60].

Although people are not interested in insurance, they are aware of the risk of floods. Therefore, they suggested combining flood mitigation measures (hard and soft measures) to avoid flood problems and to improve the efficiency and effectiveness of the mitigation strategies. The findings obtained from the flood simulation and scenarios are correlated with the perceptions of the local people. In fact, it was observed that a flood hazard map is useful for early warning by identifying high risk areas. In fact, the implementation of non-structural measures, such as an early flood warning system for flood-prone areas, can lead to reduce flood risk [52]. In addition, the implementation of WSUD can contribute to reducing the effect of a flood by improving the drainage system.

\section{Conclusions}

The assessment of flood hazards and damages in an urban watershed shows that the risk to buildings will be more serious in the future. The impacts of climate change and rapid urbanization may affect the level of flood hazard and loss. Nevertheless, the implementation of flood countermeasures, such as the preservation of lakes and the implementation of WSUD, may contribute to decreased flood impacts. Additionally, the identification of priority areas for flood risk reduction using flood hazard and damage maps will be helpful to decision-makers as they adopt strategies at local and regional scales. Flood hazard mapping can be useful for land-use planning in flood risk areas and can help urban planners prioritize their response measures. Furthermore, the uncertainty and the unpredictability of flooding are making local governments pay attention to this type of natural disaster. For this reason, a better understanding of projected flood risks will be very useful to decision-makers in adopting suitable flood control strategies and enhancing the efficiency of mitigation measures. Moreover, quantification of the annual flood loss can help establish national flood insurance programs with many options. To conclude, the prediction of future flood situations will be useful for planning and designing structural and non-structural measures. Moreover, a flood risk map might be used for early warning systems. Finally, this work can be improved by the use of high-resolution satellite images, which can 
lead to an improved identification of land-use classes. Moreover, the application of high-resolution DEM, such as LIDAR, can provide relevant results for urban flood assessments. Moreover, this study will be more significant with the assessment of a cost benefit analysis of the flood mitigation scenarios.

Acknowledgments: This research was supported by the Ministry of the Environment of Japan through the Water and Urban Initiative project and the Japan Society for the Promotion of Science (Fellowship P16790). Special thanks to the staff of the University of Economics and Business, Vietnam National University, Hanoi for their cooperation during the field survey.

Author Contributions: Mohamed Kefi designed the research and drafted the manuscript. He performed also the analysis related to flood damage. Binaya Kumar Mishra conducted the flood hazard simulation and he analyzed the results. Pankaj Kumar, Yoshifumi Masago and Kensuke Fukushi contributed to discussion of the results. Authors revised the manuscript.

Conflicts of Interest: The authors declare no conflicts of interest.

\section{References}

1. Bosher, L.; Chmutina, K. Disaster Risk Reduction for the Built Environment; Willey Blackwell: Oxford, UK, 2017.

2. Felbermayr, G.; Groschl, J. Naturally negative: The growth effects of natural disasters. J. Dev. Econ. 2014, 111, 92-106. [CrossRef]

3. Munich, R.E. Overview of Natural Catastrophe in 2016. Available online: https://www.munichre.com/ topics-online/en/2017/topics-geo/overview-natural-catastrophe-2016 (accessed on 25 November 2017).

4. Munich, R.E. Topics Geo 2016, Natural Catastrophes 2016: Analyses, Assessments, Positions. Available online: https:/ / www.preventionweb.net/publications/view/52360 (accessed on 25 November 2017).

5. IPCC. Managing the risks of extreme events and disasters to advance climate change adaptation. In A Special Report of Working Groups I and II of the Intergovernmental Panel on Climate Change; Field, C.B.V., Barros, T.F., Stocker, D., Qin, D.J., Dokken, K.L., Ebi, M.D., Mastrandrea, K.J., Mach, G.-K., Plattner, S.K., Allen, M., et al., Eds.; Cambridge University Press: Cambridge, UK; New York, NY, USA, 2012.

6. Mechler, R. Reviewing estimates of the economic efficiency of disaster risk management: Opportunities and limitations of using risk-based cost-benefit analysis. Nat. Hazards 2016, 81, 2121-2147. [CrossRef]

7. Mishra, B.K.; Herath, S. Assessment of future floods in the Bagmati River Basin of Nepal using bias-corrected daily GCM precipitation data. J. Hydrol. Eng. 2014, 20. [CrossRef]

8. Dasgupta, S.; Roy, S.; Sarraf, M. Urban flooding in a changing climate: Case study of Kolkata, India. Asian-Afr. J. Econ. Econ. 2012, 12, 135-158.

9. Jongman, B.; Kreibich, H.; Barredo, J.I.; Bates, P.D.; Feyen, L.; Gericke, A.; Neal, J.; Aerts, J.C.J.H.; Ward, P.J. Comparative flood damage model assessment: Towards a European approach. Nat. Hazards Earth Syst. Sci. 2012, 12, 3733-3752. [CrossRef]

10. De Moel, H.; Aerts, J.C.J.H. Effect of Uncertainty in land use, damage models and inundation depth on flood damage estimates. Nat. Hazards 2011, 58, 407-425. [CrossRef]

11. Merz, B.; Thieken, A.H. Flood risk curves and uncertainty bounds. Nat. Hazards 2009, 51, 437-458. [CrossRef]

12. Meyer, V.; Haase, D.; Scheuer, S. Flood risk assessment in european river basins-Concept, methods, and challenges exemplified at the mulde river. Integr. Environ. Assess. Manag. 2009, 5, 17-26. [CrossRef] [PubMed]

13. Wagenaar, D.J.; De Bruijn, K.M.; Bouwer, L.M.; De Moel, H. Uncertainty in flood damage estimates and its potential effect on investment decisions. Nat. Hazards Earth Syst. Sci. 2016, 16, 1-14. [CrossRef]

14. Jonkman, S.N.; Bockarjova, M.; Kok, M.; Bernardini, P. Integrated hydrodynamic and economic modelling of flood damage in the Netherlands. Ecol. Econ. 2008, 66, 77-90. [CrossRef]

15. Kelman, I.; Spence, R. An overview of flood actions on buildings. Eng. Geol. 2004, 73, 297-309. [CrossRef]

16. Romali, N.S.; Sulaiman, M.A.K.; Yusop, Z.; Ismail, Z. Flood Damage Assessment: A Review of Flood Stage-Damage Function Curve; Abu Bakar, S., Tahir, W., Wahid, M., Mohd Nasir, S., Hassan, R., Eds.; Springer: Singapore, 2015.

17. Pistrika, A.; Tsakiris, G.; Nalbantis, I. Flood depth-damage functions for built environment. Environ. Process. 2014, 1, 553-572. [CrossRef]

18. Smith, D.I. Flood Damage estimation-A review of Urban Stage-Damage curves and loss functions. Water $S A$ 1994, 20, 231-238. 
19. Handmer, J. The chimera of precision: Inherent uncertainties in disaster loss assessment. Int. J. Mass Emerg. Disasters 2002, 20, 325-346.

20. Thieken, A.H.; Olschewski, A.; Kreibich, H.; Kobsch, S.; Merz, B. Development and evaluation of FLEMOps-A new flood loss estimation model for the private sector. In Flood Recovery, Innovation and Response; Proverbs, D., Brebbia, C.A., Penning-Rowsell, E., Eds.; WIT Press: Southampton, UK, 2008; pp. 315-324.

21. Scawthorn, C.; Flores, P.; Blais, N.; Seligson, H.; Tate, E.; Chang, S.; Mifflin, E.; Thomas, W.; Murphy, J.; Jones, C.; et al. Hazus-MH flood loss estimation methodology. II. damage and loss assessment. Nat. Hazards Rev. 2006, 7, 72-81. [CrossRef]

22. Glas, H.; Jonckheere, M.; Mandal, A.; James-Williamson, S.; De Maeyer, P.; Deruyter, G. A GIS-based tool for flood damage assessment and delineation of a methodology for future risk assessment: Case study for Annotto Bay, Jamaica. Nat. Hazards 2017. [CrossRef]

23. Albano, R.; Sole, A.; Adamowski, J.; Mancusi, L. A GIS-based model to estimate flood consequences and the degree of accessibility and operability of strategic emergency response structures in urban areas. Nat. Hazards Earth Syst. Sci. 2014, 14, 2847-2865. [CrossRef]

24. Haq, M.; Akhtar, M.; Muhammad, S.; Paras, S.; Rahmatullah, J. Techniques of remote sensing and GIS for flood monitoring and damage assessment: A case study of Sindh province, Pakistan. Egypt. J. Remote Sens. Space Sci. 2012, 15, 135-141. [CrossRef]

25. Albano, R.; Mancusi, L.; Sole, A.; Adamowski, J. Collaborative strategies for sustainable EU flood risk management: FOSS and geospatial tools-Challenges and opportunities for operative risk analysis. ISPRS Int. J. Geo-Inf. 2015, 4, 2704-2727. [CrossRef]

26. Albano, R.; Mancusi, L.; Sole, A.; Adamowski, J. FloodRisk: A collaborative free and open-source software for flood risk analysis. Geomat. Nat. Hazard Risk 2017, 8, 1812-1832. [CrossRef]

27. Arrighi, C.; Rossi, E.; Rudari, R.; Ferraris, L.; Brugioni, M.; Franceschini, S.; Castelli, F. Quantification of Flood risk mitigation benefits: A building-scale damage assessment through the RASOR platform. J. Environ. Manag. 2018, 207, 92-104. [CrossRef] [PubMed]

28. ADB (Asian Development Bank). The Rise of Natural Disasters in Asia and the Pacific: Learning from ADB's Experience; ADB: Mandaluyong, Philippines, 2013.

29. General Statistics office of Vietnam. Statistical Yearbook of Vietnam 2016; Statistical Publishing House: Hanoi, Vietnam, 2017.

30. Hoan, P.T.T.; United Nations University Institute for the Advanced Study of Sustainability Hanoi City, Vietnam. Unpublished work, 2015.

31. Grunthal, G.; Thieken, A.H.; Schwarz, J.; Radtke, K.S.; Smolka, A.; Merz, B. Comparative risk assessment for the city of cologne-storms, flood, earthquakes. Nat. Hazards 2006, 38, 21-44. [CrossRef]

32. Foudi, S.; Oses-Eraso, N.; Tamayo, I. Integrated spatial flood risk assessment; the case of Zaragoza. Land Use Policy 2015, 42, 278-292. [CrossRef]

33. Messner, F.; Penning-Rowsell, E.; Green, C.; Meyer, V.; Tunstall, S.; Van der Veen, A. Evaluating Flood Damages: Guidance and Recommendations on Principles and Methods; FLOODsite Integrated Flood Risk Analysis and Management Methodologies Report T09-06-01; HR Wallingford: Oxfordshire, UK, 2007.

34. Skovgård Olsen, A.; Zhou, Q.; Linde, J.J.; Arnbjerg-Nielsen, K. Comparing methods of calculating expected annual damage in urban pluvial flood risk assessments. Water 2015, 7, 255-270. [CrossRef]

35. Teng, J.; Jakeman, A.J.; Vaze, J.; Croke, B.F.W.; Dutta, D.; Kim, S. Flood inundation modelling: A review of methods, recent advances and uncertainty analysis. Environ. Model. Softw. 2017, 90, 201-216. [CrossRef]

36. Mishra, B.K.; Rafiei Emam, A.; Masago, Y.; Kumar, P.; Regmi, R.K.; Fukushi, K. Assessment of future flood inundations under climate and land use change scenarios in the Ciliwung River Basin, Jakarta. J. Flood Risk Manag. 2017. [CrossRef]

37. Elliott, A.H.; Trowsdale, S.A. A review of models for low impact urban stormwater drainage. Environ. Model. Softw. 2007, 22, 394-405. [CrossRef]

38. Wu, Y.H.; Liu, K.F.; Chen, Y.C. Comparison between FLO-2D and Debris-2D on the application of assessment of granular debris flow hazards with case study. J. Mt. Sci. 2012, 10, 293-304. [CrossRef]

39. Samadi, S.Z.; Sagareswar, G.; Tajiki, M. Comparison of general circulation models: Methodology for selecting the best GCM in Kermanshah Synoptic Station, Iran. Int. J. Global Warm. 2010, 2, 347-365. [CrossRef] 
40. Akinyemi, F.O. Land Change in the Central Albertine rift: Insights from analysis and mapping of land use-land cover change in north-western Rwanda. Appl. Geogr. 2017, 87, 127-138. [CrossRef]

41. Clark Labs. Land Change Modeller for ArcGIS (Brochure). Available online: https://clarklabs.org/landchange-modeler-for-arcgis / (accessed on 25 November 2017).

42. Tu Vu, T.; Ranzi, R. Flood risk assessment and coping capacity of floods in central Vietnam. J. Hydro-Environ. Res. 2017, 14, 44-60. [CrossRef]

43. HENRD (Hanoi Environment and Natural Resources Department). Property Value Price. Available online: http:/ / www.tnmtnd.hanoi.gov.vn/ (accessed on 1 March 2017).

44. Messner, F.; Meyer, V. Flood Damage, Vulnerability and Risk Perception-Challenges for Flood Damage Research; UFZ Discussion Paper 13/2005; Department of Economics: Leipzig-Halle, Germany, 2005.

45. Moench, M.; Mechler, R.; Stapelton, S. The Costs and Benefits of Disaster Risk Management and Cost Benefit Analysis. Available online: http:/ / www.unisdr.org/files/1084_InfoNote3HLdialogueCostsandBenefits.pdf (accessed on 25 November 2017).

46. Nguyen, H.; Do Trung, H.; Dang Kinh, B.; Doan Thu, P. Assessment of flood hazard in Hanoi City. VNU J. Earth Environ. Sci. 2013, 29, 26-37.

47. Bathrellos, G.D.; Skilodimou, H.D.; Chousianitis, K.; Youssef, A.M.; Pradhan, B. Suitability estimation for urban development using multi-hazard assessment map. Sci. Total Environ. 2017, 575, 119-134. [CrossRef] [PubMed]

48. Arnell, N.W.; Gosling, S.N. The impacts of climate change on river flood risk at the global scale. Clim. Change 2016, 134, 387-401. [CrossRef]

49. Zhang, S.; Na, X.; Kong, B.; Wang, Z.; Jiang, H.; Yu, H.; Zhao, Z.; Li, X.; Liu, C.; Dale, P. Identifying wetland change in China's Sanjiang plain using remote sensing. Wetlands 2009, 29, 302-313. [CrossRef]

50. Merz, B.; Kreibich, H.; Schwarze, R.; Thieken, A. Assessment of economic flood damage. Nat. Hazards Earth Syst. Sci. 2010, 10, 1697-1724. [CrossRef]

51. Diakakis, M.; Pallikarakis, A.; Katsetsiadou, K. Using a Spatio-Temporal gis database to monitor the spatial evolution of urban flooding phenomena. The case of athens metropolitan area in greece. ISPRS Int. J. Geo-Inf. 2014, 3, 96-109. [CrossRef]

52. Komi, K.; Amisigo, B.A.; Diekkruger, B. Integrated flood risk assessment of rural communities in the Oti River Basin, West Africa. Hydrology 2016, 3, 42. [CrossRef]

53. Du, J.; Qian, L.; Rui, H.; Zuo, T.; Zheng, D.; Xu, Y.; Xu, C.-Y. Assessing the effects of urbanization on annual runoff and flood events using an integrated hydrological modeling system for Qinhuai River basin, China. J. Hydrol. 2012, 464-465, 127-139. [CrossRef]

54. Dutta, D.; Herath, S.; Musiake, K. A mathematic model for loss estimation. J. Hydrol. 2003, 227, $24-29$. [CrossRef]

55. Vietnam Central Committee for Flood and Storm Control (VCCFSC). Damage Situation Caused by Flood at Provinces in November 2008 (Annex 2); VCCFSC: Hanoi, Vietnam, 2008.

56. Neal, J.C.; Bates, P.D.; Fewtrell, T.J.; Hunter, N.M.; Wilson, M.D.; Horritt, M.S. Distributed whole city water level measurements from the Carlisle 2005 urban flood event and comparison with hydraulic model simulations. J. Hydrol. 2009, 368, 42-55. [CrossRef]

57. Rafiei Emam, A.; Mishra, B.K.; Kumar, P.; Masago, Y.; Fukushi, K. Impact assessment of climate and land-use changes on flooding behavior in the Upper Ciliwung River, Jakarta, Indonesia. Water 2016, 8, 559. [CrossRef]

58. Ramos, H.M.; Perez-Sanchez, M.; Franco, A.B.; Lopez-Jimenez, P.A. Urban floods adaptation and sustainable drainage measures. Fluids 2017, 2, 61. [CrossRef]

59. Bathrellos, G.D.; Gaki-Papanastassiou, K.; Skilodimou, H.D.; Papanastassiou, D.; Chousianitis, K.G. Potential suitability for urban planning and industry development using natural hazard maps and geological-geomorphological parameters. Environ. Earth Sci. 2012, 66, 537-548. [CrossRef]

60. Kousky, C.A. Discussion of the national flood insurance program. In Resources for the Future RFF-Policy Brief 17-01; Wharton University of Pennsylvania: Philadelphia, PA, USA, 2017.

(C) 2018 by the authors. Licensee MDPI, Basel, Switzerland. This article is an open access article distributed under the terms and conditions of the Creative Commons Attribution (CC BY) license (http:/ / creativecommons.org/licenses/by/4.0/). 